\title{
A Clinico-histopathological Correlation of Elective Abdominal Hysterectomy in University Hospital
}

\author{
Shrestha SD, ${ }^{1}$ Shrestha $\mathrm{R}^{1}{ }^{1}$ Pradhan $\mathrm{R}^{1}$ \\ ${ }^{1}$ Department of Obstetrics and Gynaecology, Patan Academy of Health Sciences, Lalitpur, Nepal. \\ Corresponding Author: \\ Dr. Sarada Duwal Shrestha \\ Patan Academy of Health Sciences, Lalitpur, Nepal \\ Email: drsshrestha@hotmail.com
}

\begin{abstract}
Introduction: The objective of this study was to correlate preoperative indications of abdominal hysterectomy with histopathological findings.

Methods: This cross-sectional study was conducted in Patan Hospital from April 2016 to March 2018 in all the patients who underwent elective abdominal hysterectomy. Demographic characteristics, clinical symptoms, preoperative diagnosis and final histopathological diagnosis were studied. Preoperative indications were correlated with histopathological diagnosis.

Results: A total of 203 elective abdominal hysterectomies were performed. Menorrhagia was the leading symptom found in $67(33.00 \%)$ patients followed by pain abdomen in 62 (30.54\%) patients. Leiomyoma was the most common preoperative diagnosis seen in 105 (51.72\%) patients followed by ovarian tumor in 34 (16.75\%) patients. The most common histopathological diagnosis was leiomyoma observed in 87 (42.86\%) patients followed by ovarian tumor in $35(17.24 \%)$ patients. Clinical and histopathological correlation was $100 \%$ in cases of ovarian tumor, complex endometrial atypical hyperplasia, pelvic inflammatory disease (PID), fibroid polyp and chronic cervicitis. Only $40 \%$ of preoperatively diagnosed postmenopausal bleeding cases were correlated histopathologically while the rest were missed preoperatively which included endometrial polyp (40\%) and adult granulosa cell tumor (20\%).

Conclusions: Leiomyoma was the most common preoperative and histopathological diagnosis. Clinical and histopathological correlation was $100 \%$ in cases of ovarian tumor, complex endometrial atypical hyperplasia, PID, fibroid polyp and chronic cervicitis.
\end{abstract}

Keywords: histopathological diagnosis; hysterectomy; preoperative indications.

\section{INTRODUCTION}

Hysterectomy is one of the most common gynaecological procedures performed worldwide. It is considered as a definitive treatment for various benign pelvic pathologies like leiyomyoma, abnormal uterine bleeding (AUB), chronic pelvic pain, endometriosis, adenomyosis, uterovaginal prolapse and genital tract malignancies. ${ }^{1}$ Histopathological examination (HPE) of hysterectomy specimens carries ethical, legal, diagnostic and therapeutic significance. ${ }^{2}$

The objective of this study was to correlate preoperative indications of abdominal hysterectomy with histopathological findings.

\section{METHODS}

This cross-sectional study was conducted in the Department of Obstetrics and Gynecology of Patan Hospital, Nepal. All the patients who underwent elective abdominal hysterectomy from April 2016 to March 2018 were included in the study. All the vaginal and obstetrics hysterectomies were excluded. The data were collected from the patient medical record files retrieved from the Medical Record Section and recorded on proformas, including demographic characteristics, clinical symptoms, preoperative diagnosis and the final histopathology results of the hysterectomy specimens. Preoperative indications were 
correlated with the histopathological diagnosis.

Microsoft Excel 2007 was used to analyze data. Ethical approval was taken from the Institutional Review Committee (IRC) of PAHS.

\section{RESULTS}

During the study period, 203 elective abdominal hysterectomies were performed. The age group of the patients ranged from 20-70 years. The maximum number of 112 (55.17\%) patients was in the age group of 40-49 years and the peak parity of $110(54.19 \%)$ patients was 2- 3 (Table 1 ).

Menorrhagia was the leading symptom found in $67(33.00 \%)$ patients followed by pain abdomen in $62(30.54 \%)$ patients (Table 2). Leiomyoma was the most common preoperative diagnosis seen in 105 (51.72\%) patients followed by ovarian tumor in $34(16.75 \%)$ patients (Table 3$)$. The most common histopathological diagnosis was leiomyoma observed in 87 (42.86\%) patients followed by ovarian tumor in 35 (17.24\%) patients (Table 4). Clinical and histopathological correlation was $100 \%$ in cases of ovarian tumor, complex endometrial atypical hyperplasia, pelvic inflammatory disease, fibroid polyp and chronic cervicitis (Table 5).

\begin{tabular}{|}
\hline \multicolumn{2}{|c|}{ Table 1. Demographic characteristics of Patients } \\
\hline \multicolumn{1}{|c|}{$\begin{array}{c}\text { Demographic } \\
\text { characteristics }\end{array}$} & $\begin{array}{c}\text { Number of } \\
\text { cases }\end{array}$ & $\begin{array}{c}\text { Percentage } \\
(\%)\end{array}$ \\
Age (years) & $<20$ & 0 & 0.00 \\
& $20-29$ & 2 & 0.99 \\
$30-39$ & 36 & 17.73 \\
& $40-49$ & 112 & 55.17 \\
$50-59$ & 39 & 19.21 \\
& $60-69$ & 12 & 5.91 \\
$\geq 70$ & 2 & 0.99 \\
Parity & Total & 203 & 100.00 \\
& 0 & 12 & 5.91 \\
1 & 29 & 14.29 \\
& $2-3$ & 110 & 54.19 \\
& $>3$ & 52 & 25.61 \\
& Total & 203 & 100.00 \\
\hline
\end{tabular}

Table 2. Distribution according to Clinical Symptoms

\begin{tabular}{|l|c|c|}
\hline Clinical Symptoms & Number of cases & $\begin{array}{c}\text { Percentage } \\
(\%)\end{array}$ \\
\hline Menorrhagia & 67 & 33.00 \\
\hline Pain Abdomen & 62 & 30.54 \\
\hline Mass Abdomen & 22 & 10.84 \\
\hline Metrorrhagia & 13 & 6.40 \\
\hline Dysmenorrhoea & 12 & 5.91 \\
\hline Menometrorrhagia & 11 & 5.42 \\
\hline Per vaginal discharge & 7 & 3.45 \\
\hline $\begin{array}{l}\text { Postmenopausal } \\
\text { bleeding }\end{array}$ & 2 & 2.46 \\
\hline Urinary symptoms & 203 & 0.99 \\
\hline $\begin{array}{l}\text { Incidental findings of } \\
\text { fibroid uterus in } \\
\text { ultrasonography }\end{array}$ & & 100.00 \\
\hline Total & & \\
\hline
\end{tabular}

Table 3. Distribution according to Preoperative diagnosis

\begin{tabular}{|l|c|c|}
\hline Preoperative diagnosis & $\begin{array}{c}\text { Number } \\
\text { of cases }\end{array}$ & Percentage (\%) \\
\hline Leiomyoma uterus & 105 & 51.72 \\
\hline Ovarian tumor & 34 & 16.75 \\
\hline Ovarian cyst & 29 & 14.29 \\
\hline $\begin{array}{l}\text { Abnormal Uterine } \\
\text { Bleeding (AUB) }\end{array}$ & 12 & 5.91 \\
\hline Adenomyosis & 10 & 4.93 \\
\hline Postmenopausal bleeding & 5 & 2.46 \\
\hline $\begin{array}{l}\text { Cervical Intraepithelial } \\
\text { Neoplasia (CIN) }\end{array}$ & 3 & 1.48 \\
\hline Complex endometrial \\
atypical hyperplasia
\end{tabular}


Shrestha et al. A Clinico-Histopathological Correlatation of Elecgive..

\begin{tabular}{|l|c|c|}
\hline \multicolumn{3}{|l|}{$\begin{array}{l}\text { Table 4. Distribution according to Histopathological } \\
\text { diagnosis }\end{array}$} \\
$\begin{array}{l}\text { Histopathological } \\
\text { diagnosis }\end{array}$ & $\begin{array}{c}\text { Number of } \\
\text { cases }\end{array}$ & Percentage (\%) \\
\hline Leiomyoma & 87 & 42.86 \\
\hline Ovarian tumor & 35 & 17.24 \\
\hline Ovarian cyst & 28 & 13.80 \\
\hline Adenomyosis & 16 & 7.88 \\
\hline $\begin{array}{l}\text { Leiomyoma + } \\
\text { Adenomyosis }\end{array}$ & 13 & 6.40 \\
\hline Chronic cervicitis & 6 & 2.96 \\
\hline Endometrial Polyp & 3 & 1.48 \\
\hline $\begin{array}{l}\text { Complex endometrial } \\
\text { atypical hyperplasia }\end{array}$ & 2 & 0.99 \\
\hline $\begin{array}{l}\text { Cervical Intraepithelial } \\
\text { Neoplasia (CIN) }\end{array}$ & 1 & 0.49 \\
\hline Acute endometritis & 1 & 0.49 \\
\hline Fibroid polyp & 1 & 0.49 \\
\hline Tubo-ovarian abscess & 1 & 0.49 \\
\hline Unremarkable & 9 & 4.43 \\
\hline Total & 203 & 100.00 \\
\hline
\end{tabular}

Table 5. Correlation between preoperative diagnosis and histopathological diagnosis $(n=203)$

\begin{tabular}{|c|c|c|c|c|}
\hline $\begin{array}{l}\text { Preoperative } \\
\text { diagnosis }\end{array}$ & $\begin{array}{l}\text { Number } \\
\text { of cases }\end{array}$ & \multicolumn{2}{|l|}{$\begin{array}{l}\text { Histopathological } \\
\text { diagnosis }\end{array}$} & $\begin{array}{l}\text { Percentage } \\
\text { Correlated } \\
(\%)\end{array}$ \\
\hline \multirow{5}{*}{$\begin{array}{l}\text { Leiomyoma } \\
\text { uterus }\end{array}$} & \multirow[t]{5}{*}{105} & Leiomyoma & 87 & \multirow[t]{5}{*}{82.86} \\
\hline & & $\begin{array}{l}\text { Leiomyoma + } \\
\text { Adenomyosis }\end{array}$ & 11 & \\
\hline & & Adenomyosis & 5 & \\
\hline & & $\begin{array}{l}\text { Acute } \\
\text { endometritis }\end{array}$ & 1 & \\
\hline & & Unremarkable & 1 & \\
\hline \multirow[t]{6}{*}{ Ovarian tumor } & \multirow[t]{6}{*}{34} & $\begin{array}{l}\text { Serous } \\
\text { cystadenoma }\end{array}$ & 13 & \multirow[t]{6}{*}{100.00} \\
\hline & & $\begin{array}{l}\text { Mature cystic } \\
\text { teratoma }\end{array}$ & 12 & \\
\hline & & $\begin{array}{l}\text { Mucinous } \\
\text { cystadenoma }\end{array}$ & 4 & \\
\hline & & $\begin{array}{l}\text { Borderline } \\
\text { mucinous tumor }\end{array}$ & 3 & \\
\hline & & $\begin{array}{l}\text { Borderline } \\
\text { brenner tumor }\end{array}$ & 1 & \\
\hline & & Fibroma & 1 & \\
\hline
\end{tabular}

\begin{tabular}{|c|c|c|c|c|}
\hline \multirow[t]{5}{*}{ Ovarian cyst } & \multirow[t]{5}{*}{29} & $\begin{array}{l}\text { Endometriotic/ } \\
\text { chocolate cyst }\end{array}$ & 23 & \multirow[t]{5}{*}{96.55} \\
\hline & & $\begin{array}{l}\text { Hemorrhagic } \\
\text { cyst }\end{array}$ & 3 & \\
\hline & & $\begin{array}{l}\text { Corpus luteal } \\
\text { cyst }\end{array}$ & 1 & \\
\hline & & Simple cyst & 1 & \\
\hline & & $\begin{array}{l}\text { Tubo-ovarian } \\
\text { abscess }\end{array}$ & 1 & \\
\hline \multirow{4}{*}{$\begin{array}{l}\text { Abnormal } \\
\text { Uterine } \\
\text { Bleeding (AUB) }\end{array}$} & \multirow[t]{4}{*}{12} & Unremarkable & 6 & \multirow[t]{4}{*}{50.00} \\
\hline & & Adenomyosis & 4 & \\
\hline & & $\begin{array}{l}\text { Endometrial } \\
\text { polyp }\end{array}$ & 1 & \\
\hline & & Chronic cervicitis & 1 & \\
\hline \multirow[t]{3}{*}{ Adenomyosis } & \multirow[t]{3}{*}{10} & Adenomyosis & 7 & \multirow[t]{3}{*}{70.00} \\
\hline & & $\begin{array}{l}\text { Leiomyoma + } \\
\text { Adenomyosis }\end{array}$ & 2 & \\
\hline & & Chronic cervicitis & 1 & \\
\hline \multirow[t]{3}{*}{$\begin{array}{l}\text { Postmenopausal } \\
\text { bleeding }\end{array}$} & \multirow[t]{3}{*}{5} & $\begin{array}{l}\text { Endometrial } \\
\text { polyp }\end{array}$ & 2 & \multirow[t]{3}{*}{40.00} \\
\hline & & Unremarkable & 2 & \\
\hline & & $\begin{array}{l}\text { Adult granulosa } \\
\text { cell tumor }\end{array}$ & 1 & \\
\hline \multirow{2}{*}{$\begin{array}{l}\text { Cervical } \\
\text { Intraepithelial } \\
\text { Neoplasia (CIN) }\end{array}$} & \multirow[t]{2}{*}{3} & CIN & 1 & \multirow[t]{2}{*}{33.33} \\
\hline & & Chronic cervicitis & 2 & \\
\hline $\begin{array}{l}\text { Complex } \\
\text { endometrial } \\
\text { atypical } \\
\text { hyperplasia }\end{array}$ & 2 & $\begin{array}{l}\text { Complex } \\
\text { endometrial } \\
\text { atypical } \\
\text { hyperplasia }\end{array}$ & 2 & 100.00 \\
\hline $\begin{array}{l}\text { Pelvic } \\
\text { Inflammatory } \\
\text { Disease (PID) }\end{array}$ & 1 & Chronic cervicitis & 1 & 100.00 \\
\hline Fibroid polyp & 1 & Fibroid polyp & 1 & 100.00 \\
\hline $\begin{array}{l}\text { Chronic } \\
\text { cervicitis }\end{array}$ & 1 & Chronic cervicitis & 1 & 100.00 \\
\hline
\end{tabular}

\section{DISCUSSION}

In our study, the most common age group was 40-49 years which constituted of 112 (55.17\%) patients who underwent elective abdominal hysterectomy. This finding was similar to previous studies. $^{2-7}$

In the present study, the maximum number of 110 (54.19\%) patients was seen with parity $2-3$ which was comparable to other studies. ${ }^{3,8}$

The most common clinical symptom in this study was menorrhagia found in $67(33.00 \%)$ patients followed by pain abdomen in $62(30.54 \%)$ patients which were similar to the studies done by Jaleel R, Perveen S and Naheed K., 6, 9 It is well known that 
hormonal disturbance in the perimenopausal age group, results in symptomatic menstrual changes. ${ }^{6}$ In this study, the most common preoperative diagnosis for hysterectomy was leiomyoma uterus found in $105(51.72 \%)$ patients followed by ovarian tumor in $34(16.75 \%)$ patients which were similar to the results reported by Acharya S. ${ }^{7}$ Jha R. found that leiomyoma was the indication in $24.9 \%$, ovarian tumor in $14.9 \%$, and DUB in $7.7 \%$ of the cases. ${ }^{10}$ Similar results were observed in the studies done by Yadav DP, Jaleel R and Naheed $\mathrm{K}^{2,3,9}$

In our study, the most common histopathological diagnosis was leiomyoma, found in 87 (42.86\%) patients, as similar to other studies, ${ }^{2,4}$ Ovarian tumor observed in $35(17.24 \%)$ patients was the next common pathology found in this study whereas adenomyosis was also the next common pathology found in other studies. ${ }^{2,4,10,11}$

In this study, the correlation between preoperative diagnosis and histopathological diagnosis was $100.00 \%$ in cases of ovarian tumor, complex endometrial atypical hyperplasia, PID, fibroid polyp and chronic cervicitis whereas it was $96.55 \%$ in ovarian cyst and $82.86 \%$ in leiomyoma, comparable to previous studies. ${ }^{3,7,10,12}$ However, double pathologies of leiomyoma and adenomyosis coexisted in 11 patients (10.47\%). Adenomyosis was found in 5 patients $(4.77 \%)$ with preoperative diagnosis of leiomyoma while acute endometritis was found in 1 patient (0.95\%) whereas no pathology was identified in 1 patient $(0.95 \%)$ in histopathological diagnosis.

Adenomyosis is rarely diagnosed preoperatively and is still largely under diagnosed as it has non-specific physical findings. ${ }^{9}$ In our study, the correlation between preoperative diagnosis and histopathological diagnosis of adenomyosis was $70 \%$, similar to the study done by Jaleel R. ${ }^{2}$ However, double pathologies of adenomyosis and leiomyoma coexisted in 2 patients (20\%). Chronic cervicitis was found in 1 patient (10\%) with preoperative diagnosis of adenomyosis in histopathological diagnosis.
Abnormal uterine bleeding (formerly, dysfunctional uterine bleeding [DUB]) is a diagnosis of exclusion. ${ }^{2}$ In our study, preoperative diagnosis of AUB was made in 12 (5.91\%) patients. However, $50 \%$ of preoperatively diagnosed AUB cases were correlated with histopathological diagnosis while the rest were missed preoperatively which included adenomyosis (33.33\%), endometrial polyp (8.33\%) and chronic cervicitis (8.33\%). This result emphasized the fact that the preoperative diagnosis of AUB should be made only after the analysis of comprehensive and necessary investigations. This result also sufficiently highlights the importance of histopathological examination of all surgical specimens. In the study conducted by Yadav DP et al, AUB was found in 27 (25.71\%) patients in which AUB was histopathologically correlated in 2 (7.40\%) patients. ${ }^{3}$

In our study, the preoperative symptomatic diagnosis of postmenopausal bleeding was made in $5(2.46 \%)$ patients. Only $40 \%$ of preoperatively diagnosed postmenopausal bleeding cases were correlated on histopathological diagnosis while the rest were missed preoperatively which included endometrial polyp (40\%) and adult granulosa cell tumor (20\%). Therefore, a thorough histopathological confirmation is necessary not only to substantiate the preoperative diagnosis but also to find out missed pathologies, especially malignancies.

In our study, the preoperative diagnosis of cervical intraepithelial neoplasia was found in 3 (1.48\%) patients. However, $33.33 \%$ of preoperatively diagnosed cervical intraepithelial neoplasia were correlated on histopathological diagnosis whereas 2 cases $(66.67 \%)$ had chronic cervicitis. These findings were consistent with previous studies. ${ }^{5,7}$

Many times, histopathological examination of hysterectomy specimens does not reveal any pathology. ${ }^{10}$ In our study, 9 (4.43\%) patients had unremarkable pathology who were operated with preoperative diagnosis of AUB (6 cases), leiomyoma uterus (1 case) and postmenopausal bleeding ( 2 cases). These findings were consistent with the study done by Jha R. ${ }^{10}$ 


\section{CONCLUSIONS}

In this study, leiomyoma was the most common preoperative and histopathological diagnosis. Clinical and histopathological correlation was $100 \%$ in cases of ovarian tumor, complex endometrial atypical hyperplasia, PID, fibroid polyp and chronic cervicitis.

\section{Conflict of Interest: None}

\section{REFERENCES}

1. Nausheen F, Iqbal J, Bhatti FA, Khan AT, Sheikh S. Hysterectomy: the patient's perspective. Ann Gyne. 2004;10:339-41

2. Jaleel R, Khan A, Soomro N. Clinico-Pathological study of abdominal hysterectomies. Pak J Med Sci 2009;25(4):630-634

3. Yadav DP et al. Abdominal hysterectomy: analysis of clinico-histopathological correlation in Western Rajasthan, India. Int J Reprod Contracept Obstet Gynecol. 2017 Mar;6(3):1012-1015. DOI: http:// dx.doi.org/10.18203/2320-1770.ijrcog20170575

4. Arulnathan Ebinesh, MS Sharada, MC Krishna. Clinicopathological correlation of abdominal hysterectomy specimens. International Journal of Science and Research (IJSR) 2013; 4:1084-89

5. Verma D et al. Analysis of histopathological examination of the hysterectomy specimens in a north Indian teaching institute. Int J Res Med Sci. 2016 Nov;4(11):4753-4758. DOI: http://dx.doi.org/10.18203/2320-6012. ijrms20163761

6. Perveen S, Tayyab S. A clinicopathological review of elective abdominal hysterectomy. Journal of Surgery Pakistan (International) 2008 Jan-Mar;13 (1);26-29

7. Acharya S, Shrestha S, Pal M. N. A retrospective review of abdominal hysterectomy in a teaching hospital. Journal of Universal College of Medical Sciences 2015; 3(10):16-19. DOI: http://dx.doi.org/10.3126/jucms.v3i2.14285
8. Ticku et al. Histopathological spectrum of hysterectomy specimens in tertiary care hospital: A prospective study. Ejbps 2017;4(8):858-866

9. Naheed K, Hussain A, Ali R. Clinico-pathological study of hysterectomy at Pak Red Crescent Medical and Dental College. JIIMC 2018;13(2): 62-65

10. Jha et al.Histopathological Analysis of Hysterectomy Specimens. J Nep Med Assoc 2006; 45:283-290

11. Gupta G, Kotasthane D, Kotasthane V.Hysterectomy: A Clinico-pathological correlation of 500 cases. The Internet J Gynaecol Obs. 2009:14:1

12. Gangadharan V, Prasanthi C. Hysterectomy - a clinico- pathological correlation in a rural setting. Indian Journal of Basic and Applied Medical Research. March 2016; 5(2):8-15 